\title{
Internet of Things as Innovative Technology in Retailing
}

\author{
„Интернет ствари“ као иновативна технологија са \\ применом у малопродаји \\ Sonja Vučenović ${ }^{*}$ \\ University of Novi Sad, Faculty of Economics in Subotica, Subotica
}

\begin{abstract}
The Internet of Things (loT) or Internet of everything gives new opportunities to retailers by linking each consumer with the retail facility and the activities it performs in the purchasing process by connecting to Internet and combining physics and the virtual world. In the modern world, the amount of business data is growing steadily, raising the question of how to manage it main occupation of retailers. The key factor in introducing Internet of Things in retail is reducing costs. Internet of things in retailing is the connection between physical sales facilities and products and the virtual world of retailers and consumers. Implementation of Internet of Things involves application of technology in retail store, use of mobile devices by consumers, interaction with the consumer, the availability of data on the cloud or on social networks, as well as the backend system, the infrastructure for collecting, monitoring, storing and processing data.
\end{abstract}

Keywords: digitalization, Internet of Things, retail store, consumer, Internet.

Сажетак: „Интернет ствари“ или „интернет свега“ пружа нове могућности за малопродавце тако што повезује сваког потрошача с малопродајним објектом и активностима које обавља у процесу куповине, повезивањем на интернет и комбиновањем физике и виртуелног света. У савременом свету, количина података из пословања се непрекидно повећава, а главна преокупација малопродаваца постаје начин управљања подацима. Кључни фрактор увођења интернета ствари у малопродају јесте смањење трошкова. Интернет ствари у малопродаји јесте веза између физичких продајних објеката и производа и виртуелног света трговаца и потрошача. Примена интернета ствари подразумева примену технологије у малопродаји, коришћење мобилних уређаја од стране потрошача, интеракцију с потрошачем, доступност података на облаку посредством програма лојалности или друштвених мрежа, као и позадински систем, инфраструктура за сакупљање, праћење, чување и обраду података.

Кључне речи: дигитализација, интернет ствари, малопродајни објекат, потрошач, интернет.

\section{Introduction}

The application of the Internet of Things (IoT) was initially inconceivable in the retail sector, but nowadays it becomes a way of achieving the competitiveness of the world's leading retailers. Internet of Things in retailing is the connection between the physical sales facilities and products and the virtual world of retailers and consumers. Even though there have already been technologies that include tracking products through a supply chain, and end to using products by consumers, such as RFID, Internet of Things implies a higher level of consumer involvement in the entire process, with an emphasis on ease of shopping. There are many concerns about the storage of large amounts of data,

\footnotetext{
* ssonjavucenovic1@ef.us.ac.rs
} 
as well as the issues of consumer safety and privacy. There is a question of whether consumers will soon be making purchases in a shelf-free store without products with virtual displays and touch screen options through which consumers will choose products that will wait for them packed and ready at the store exits, or to go further, delivered to consumers' home and waiting for them before entering home. Such a future concept of purchase will be supported by the Internet of things.

\section{Next stage in retail technology development and implementation}

The evolution of new retail technologies entitles that the previous decade is considered as the era of electronic retail, while in the coming period it will dominate in the development of technology in traditional retail (Končar, Vučenović \& Petrović Katai, 2017). What was not characteristic for the largest "pure play" electronic retailers is that they enter the traditional retail market, as is the case of AmazonGo, which opened retail facilities. As the largest "pure play" retailer they offered consumers a new concept of retail and shopping experience without sales force, rows, receipts, with mobile payments and thus made a revolution in traditional retail.

Figure 1: Evolution of technologies in retail

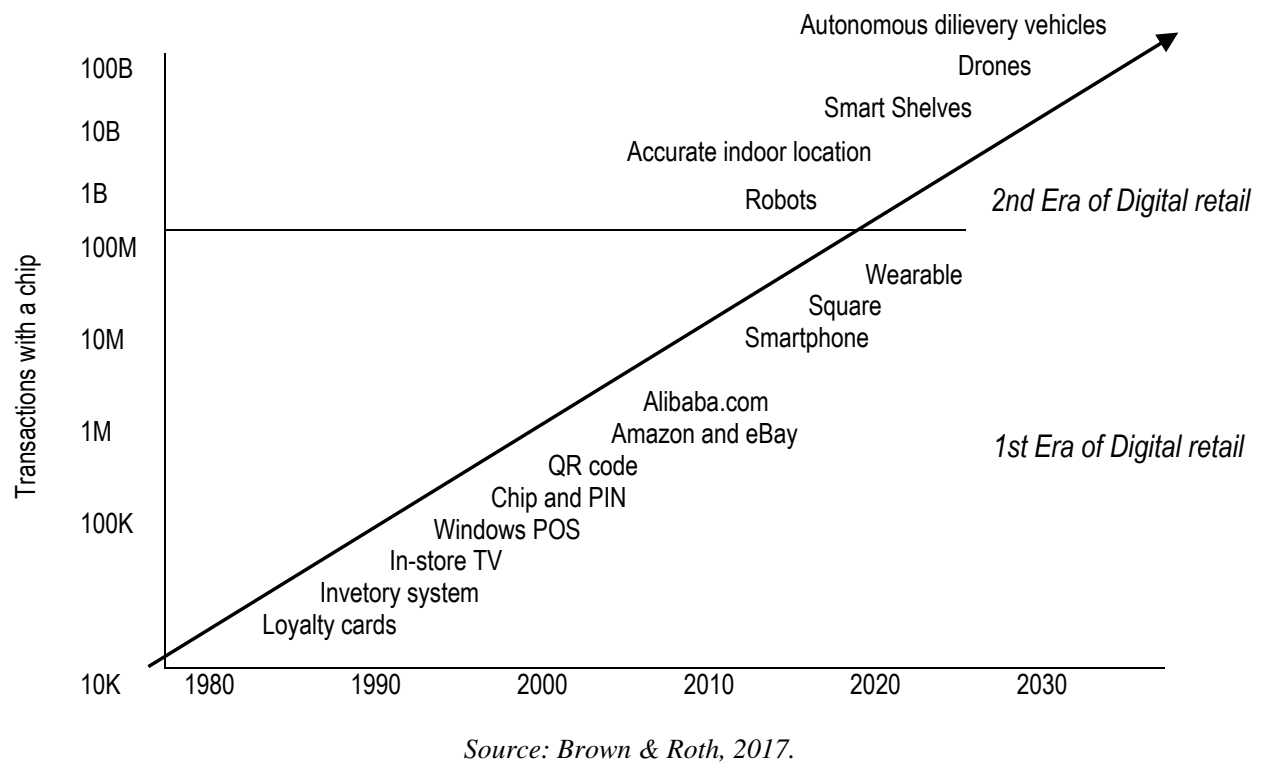

The effects of evolution of new technology in retail had been noticeable in electronic retail by the middle of the first decade of the 21 st century domination, however, further development of technologies applicable to retail stores will have a more significant impact (Končar, Vučenović \& Petrović Katai, 2017). So far, electronic 
retailing has been an innovative retail format with growing share in total retail sales, but moving Amazon.com to the traditional retail market shows that online business does not see room for its further development.

Retailers also used RFID technology in their business in the previous period. With the advent of new technologies, improved sensors, better Internet connection, ease of communication and mobile devices, they have made the Internet a thing in retail use, and have also brought opportunities to improve business and personalized purchasing experiences.

Internet of things (IoT) or Internet of everything, with implementation in retailing connects the physical sales object and products and the virtual world of retailers and consumers. The Internet of Things presents an opportunity for retailers to develop a vastly improved ecosystem that connects physical and digital worlds allowing bidirectional real-time interaction with consumers both inside and outside the store (Gregory, 2015). The Internet of Things gives new opportunities to retailers by linking each consumer with the retail store and the activities it carries out in the purchasing process by connecting to Internet and combining physics and the virtual world. Digitization is becoming a growing trend in the retail sector that has always been a laborintensive sector, and today the human workforce is being increasingly replaced by technology. Thanks to the Internet of Things, retailers cannot just perform their operations more efficiently but can also make it easier to get into more and more marketing channels.

Multi-channel, omni-channel, mobile, social, showrooming, internet of things, big data, wearables, gamification - the never-ending list of trends and innovations reflects the rapid pace of change in the retail industry (Bcx, 2016). The application of Internet of Things becomes the future of technology development by retailers who, through technology, find ways to become competitive. Owing to the Internet of Things, the buying experience is improved.

The Internet of Things creates a boost for the development of multichannel approach using interactive devices and various mobile applications. There are also nontraditional ways of selling products outside the retail facility, such as interactive electronic kiosks at a retail store or at attractive locations. Many manufacturers set up electronic kiosks in retail stores, that is, retailers also set up their own electronic kiosks to make it easier for consumers to shop, move through a retail store, or buy a certain product category (cigarettes, magazines, etc.). Internet retail kiosks provide access to the Internet and electronic store where consumers order products and determine the place where the product is being delivered. Boots' uses an advanced loyalty program, enables the personal data of consumers to be read through electronic kiosk in the retail facility and provide a personalized offer based on the points collected or the ability to check the points collected. Electronic kiosks facilitate search on the Web and are often used in a 
retail store to search for product availability in the store or order the product, pay for it electronically, and process the account for delivery to the home address.

On the other hand, innovations in digital fabrication, machine-to-machine communication, and wearable computing will lead to the emergence of an "Internet of Things," in which material goods become far more fungible and customizable than they are today (Pwc, 2016). Amazon has gone a step further in the application of Internet things, including the consumer to scan products with smartphone while entering the store. With a mobile phone, the consumer performs identification after entering the store, scans the products that are taken from the shelves and pays when leaving the store, with minimal instructions from the consumers and the cost of the time. Computer vision, sensor fusion, and deep learning technologies automatically detect when products are taken from or returned to shelves and keep track of items in a virtual cart. After consumers leave the store, they are charged and sent an automatic receipt (Grewal, Roggeveen \& Nordfält, 2017).

Modern retail stores include the implementation of modern technologies and the use of the Internet in order to enhance the consumer's purchasing experience. They are equipped with smart mirrors, a variety of virtual screens with touch screen technology, virtual changing rooms, product display screens, product scanners, consumer and product tracking in a retail store, and are used by Tesco, M\&S, Sonny, Burberry, Apple, Disney and others. In this way, traditional retailers integrate Internet of Things into a retail store, making Internet of things an indispensable part of the buying experience and decision-making process for purchasing, as well as a way of achieving a competitive edge in retail business with a competitive advantage over the competition.

\section{Internet of Things as a factor of efficiency of retail operations}

In the modern world, the amount of business data is constantly increasing; in retail it means tracking each individual consumer, his every purchase and storage of data, giving retailers room for making decisions about performance in relation to consumers. Many European firms are active in fast-growing areas, capturing 20 to 30 percent of revenue in big data and Internet of Things applications in the case of the largest digitized businesses (McKinsey Global Institute, 2016). The necessity of applying such a technology to retailing is reflected in the number of data available to retailers in everyday business, from product data to consumer data. The Internet of things enables monitoring of each individual product from the supplier to the process of consumer spending, which should have the effect of reducing the distribution costs.

Yet even as the Internet's place in retail strategy has come to define the new norm, another suite of technology, the Internet of Things (IoT), threatens to reshape the competitive landscape again (Kambies, Raynor \&Pankratz, 2016). A key factor in introducing Internet of Things in retail is reducing costs. But the introduction of 
technology implies high initial costs, sensor installation, maintenance, data collection, and data warehousing, which requires software, as well as knowledge in this area. Therefore, no matter the admission to the digitization of retailing, the costs pressures will not hold small retailers, with little interest to introduce the Internet of Things. It is known that there are restrictions even on the introduction of electronic payments with small retailers operating with only one or a few retail stores and performing locally.

Thanks to the Internet, it is possible to monitor consumer information more effectively through loyalty program following their buying habits and preferences. Prior to the implementation of Internet of things, retailers assessed the effects it will have on their business. The big threat is data management and security of consumers' data.

The fact that the second era of digital retail is already in well under way indicates that the future of retailing is in this technology as fully $10 \%$ of all IOT (Internet of Things) investment in 2013 was made in retail precisely, and by 2017 they estimate that annual IOT investment by retailers will exceed $\$ 466$ million (Brown \& Roth, 2017). The use of computers is ubiquitous in all areas and the use of data from all sources of business implies the use of Internet of Things. Today, every mobile phone becomes a personal computer used for accessing the Internet and is used intensively in the buying process. The increasing spread of applications for mobile payments and mPOS terminals make it possible to dispose of resources in a more flexible way. The Internet of things does not exist only in the data collection segment, but becomes crucial in analyzing data and making decisions based on the collected data.

\section{Implementation of Internet of Things in Retailing}

The following eight disruptive technologies are critical for transformation of retailing (World Economic Forum, 2017): the Internet of Things (IoT), autonomous vehicles $(\mathrm{AV}) /$ drones, robotics, artificial intelligence (AI)/machine learning, augmented reality (AR)/virtual reality (VR), digital traceability, 3D printing and blockchain. Internet of things in a retail store includes the implementation of a range of equipment, from vending machines, interactive screens, virtual cabinets and smart mirrors, digital signals, connected cameras and smart shelves.

Internet of things will become a future for many retail processes, such as inventory management and others. Contemporary retail store supported by Internet of Things technology include shelves, smart packaging and enable product tracking and reaction as soon as the product reaches a lower level of inventory. As illustrated in Figure 2, the implementation of Internet of things involves the application of technology in a retail store, use of mobile devices by consumers, interaction with the consumer, the availability of data on the cloud trough loyalty programs or on social networks, as well as the backend system, the infrastructure for collecting, monitoring, storing and processing data. 
Figure 2: Implementation of Internet of Things in a Retail Stores

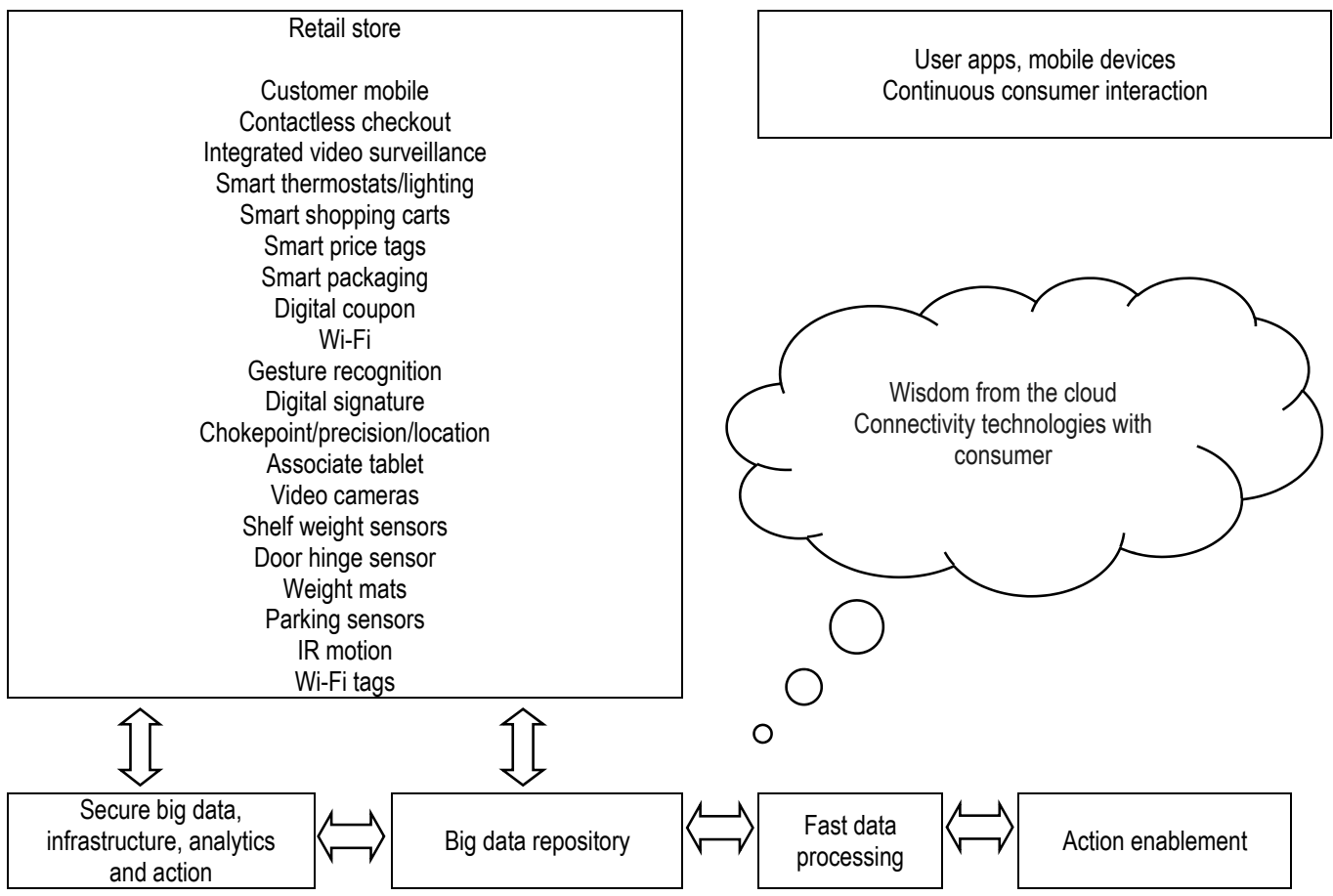

Source: Author based on (EIMESC, 2015).

Scanning and paying for products will be done remotely until the consumer leaves the store with goods. Thanks to the sensors, there is no more need for scanning each product one by one at the cash registers. The product packaging will read the sensors at the exit from the store, which will send the signal to the applications in the mobile phones of the consumer and make payments.

Some of the modern technologies that will provide a better buying experience and product experience are (Morya et al., 2016):

1. Virtual product zone - provides infinite product shelf to retailers and convenience and variety to customers;

2. Experience zone - without using trial rooms, customer can conveniently try on multiple products virtually;

4. Virtual simulation of retail theater - without using trial rooms, customer can conveniently try on multiple products virtually;

5. Physical product on display - customers can scan the tags of physical merchandise and use the experience zone to virtually try them on themselves; 
6. Prototypic zone - customers can customize the products (shape, size, design, colors, fit, etc.) according to their needs.

3D printing technology allows stores to create their own products on demand. In addition, many products can be printed locally, reducing transportation, storage, and logistics costs. Also, virtual reality deeply transforms and expands shopping experiences from home or in stores. Consumers will be able to explore products in the virtual world before buying.

\section{Conclusion}

Digitization is becoming a growing trend in the retail sector. Further development of the technologies applicable to retail store will have increasing impact. Electronic retailing has been an innovative retail format whose share in total retail sales has grown, but recently retailers do not see their further development in electronic retailing. With the advent of new technologies, improved sensors, a better connection, ease of communication and mobile devices, Internet of Things becomes technology of future. The Internet of Things creates a boost for the development of multichannel approach using interact action with consumers through many channels. Modern retail stores include the implementation of modern technologies and the use of the Internet in order to enhance the consumer's purchasing experience. The second era of digital retail is already underway, as by 2017 annual IOT investment by retailers will exceed $\$ 466$ million. The Internet of Things is one of eight technologies that will have huge impact on retailers' business in future, together with autonomous vehicles (AV)/drones, robotics, artificial intelligence (AI)/machine learning, augmented reality (AR)/virtual reality (VR), digital traceability, 3D printing and blockchain.

\section{References}

Bcx (2016). Retail in a Digitalized Future. Bcx.

Brown, S., Roth, D. (2017). The Second Era of Digital Retail - A Vision for the Future of Shopping and the Smart Shelf. Intel.

Gregory, J. (). The Internet of Things: Revolutionizing the Retail Industry. Accenture.

Grewal, D., Roggeveen, A. L., Nordfält, J. (2017). The Future of Retailing. Journal of Retailing. 93 (1,) 1-6.

Kambies, T., Raynor, M. E., Pankratz, D. E. (2016). Closing the digital divide IoT in retail's transformative potential. Deloitte University press.

Končar, J., Vučenović, S., Petrović Katai, Z. (2018). Digitalizacija maloprodaje na globalnom tržištu. Zbornik radova sa XXIII međunarodne naučno - stručne konferencije INFORMACIONE TEHNOLOGIJE - sadašnjost i budućnost, 19-24. februar 2018., Univerzitet Crne Gore, 76-78. 
McKinsey Global Institute (MGI) (June 2016). Digital Europe: Pushing the Frontier, Capturing the Benefits. McKinsey Global Institute.

Morya, A., Nigam, A., Rehman, F., Kumar, A. (July 2016). The Digital Retail Theater: Shopping's Future. Cognizant 20-20 insights, 1-9.

Pwc (2013). The Digital Future of Creative Europe, the economic impact of digitization and the Internet on the creative sector in Europe. PWC.

World Economic Forum (January 2017). Shaping the Future of Retail for Consumer Industries. Geneva: World Economic Forum.

EIMESC (2015). Internet of Things (IoT) Introduction. Accessed 15 May 2018, available at: http://www.eimesc.co.il/internet-of-things-iot/.

\section{Summary}

The application of the Internet of Things (IoT) was initially inconceivable in the retail sector. This technology in retailing makes the connection between the physical sales facilities and products and the virtual world of retailers and consumers. Internet of Things implies a higher level of consumer involvement in the entire process. As it is otherwise called Internet of everything in retailing connects the physical sales object and products and the virtual world of retailers and consumers. The Internet of Things presents an opportunity for retailers to develop a vastly improved system allowing real-time interaction with consumers both inside and outside the store. It gives new opportunities to retailers by linking each consumer with the retail store and the activities it carries out through the purchasing process, by connecting to the Internet. The Internet of things enables the monitoring of each individual product from the supplier to the process of consumer spending, which should have, among other effects, reduction in the distribution costs. Its implementation demands application of technology in a retail store, use of mobile devices by consumers, interaction with the consumer, the availability of data on the cloud, trough loyalty programs or on social networks, as well as the backend system. 